\title{
An Ethical Response to Corruption in Kenya
}

\author{
Joseph Ouma Oindoํ, Edward Oyugi' ${ }^{1}$ Zacharia Samita ${ }^{2}$ \\ ${ }^{1}$ Institute for Social Transformation, Tangaza University College, Nairobi, Kenya \\ ${ }^{2}$ Kenyatta University, Nairobi, Kenya \\ Email: oumaoindo@yahoo.co.uk
}

How to cite this paper: Oindo, J.O., Oyugi, E. and Samita, Z. (2021) An Ethical Response to Corruption in Kenya. Open Access Library Journal, 8: e7986.

https://doi.org/10.4236/oalib.1107986

Received: September 21, 2021

Accepted: October 25, 2021

Published: October 28, 2021

Copyright $\odot 2021$ by author(s) and Open Access Library Inc.

This work is licensed under the Creative Commons Attribution International License (CC BY 4.0).

http://creativecommons.org/licenses/by/4.0/

\begin{abstract}
This paper explores an ethical response to corruption in Kenya. The study is based on a literature review. The principle method used is the analysis of historical records that show how African moral theory, with particular reference to Ubuntu morality, can be applicable to the development of a national ideology of the common good to curb persistent corruption in Kenya. Through document analysis, the study found out that African ethics resonates with the indigenous worldview of Africans and can effectively be employed as an anti-corruption tool in Kenya. Therefore, this study has highlighted the need for the Church in Kenya, in the formation of public conscience, to utilize moral principles of Ubuntu that are germane to Kenyans as a pastoral tool to curb a run-away corruption in Kenya.
\end{abstract}

\section{Subject Areas}

Sociology

\section{Keywords}

Moral Development, Moral Values, Corruption, Virtues, Ubuntu

\section{Introduction}

This study was informed by the researcher's experience of nepotism at the Laikipia County Lands' offices in Nanyuki Town and also at the Machakos County Land's offices, in Machakos Town. In Nanyuki, the researcher had gone to process land title deed for a parcel of land he owns at Olmoran in Laikipia west. In Machakos, the researcher similarly went to process a title deed for a parcel of land he owns in Machakos County. In these instances, the researcher noted that there were those service seekers who barely queued. There were those who queued for the services, but there were those who could simply make phone calls to certain officials inside the lands offices and their documents would be taken through the 
window. These experiences (Laikipia and Machakos Counties) made the researcher to question the nature of linkages existing between the land officers and those service seekers whose services were attended to faster than the others. This study therefore proceeded with an assumption that one of the factors behind corruption in Kenya is ethnic linkages. As a result this study argues that Ubuntu morality is an ideal theoretical framework to tackle corruption in Kenya as it informs relationships in African setup.

\subsection{Background to the Study}

Corruption is understood is a situation in which a public officer uses public resources for personal gain. Historically, corruption can be traced as far back as to the ancient philosophers and continues to halt development globally (Dimant, 2013) [1]. While in Tanzania, corruption is a deterrent to the ease of doing business (Ngussa, Makewa, \& Allida, 2016) [2], in Kenya corruption pervades various sectors of the society. Money destined for youth programs disappear into individuals' bank accounts. Medical doctors squander resources in public hospitals; and accountants rob public funds through the manipulation of the accounting systems (Mwenzwa, 2013) [3].

In the healthcare sector, the Kenya Anti-Corruption Commission (KACC) then identified healthcare fraud when patients pay medical bills through insurance companies and bills get inflated by hospital management, including billing services not rendered. The healthcare sector is also dotted with theft of drugs and medical supplies by medical practitioners, diversion of drugs from public hospitals to private facilities, unnecessary referral of patients to private clinics that are either owned or are linked to the doctors in the public hospitals (KACC, 2010) [4]. Corruption has again been cited as pervasive, not only in the healthcare system, but also at the national and county governments (EACC, 2016) [5] levels.

\subsection{Problem Statement}

Despite the efforts to curb corruption, both internationally and in Kenya, corruption continues to impede development and undermine social transformation. In Kenya, presences of an anti-corruption institution and parliamentary oversight bodies have had little or no effect on the control of public sector corruption. Corruption continues to fuel inequality across the country, and according to the National Cohesion and Integration Commission (NCIC) (2016) [6] counties continue to recruit and promote employees from single ethnic communities (dominant) due to fear of the unknown. The unknown, in this scenario, may mean the fear of an employee from a minority ethnic community becoming a whistle-blower in the event of a corrupt practice by the dominant group in the county (Oindo, Oyugi, \& Samita, 2021) [7].

Amidst this persistent corruption in Kenya, this present study argues that the moral aspect of the common good is insufficiently acknowledged in Kenya and 
yet it is an essential component in the realization of Kenya's sustainable development agenda. This paper essentially argues that the pedagogy of sustainable development involves a shift in norms and values and requires moral formation with the aim of creating a national ideology of the common good in Kenya. Therefore, this paper has identified African Ubuntu morality as the plausible discourse in the control of public sector corruption in Kenya as it is the ethical discourse that is indigenous to the people of Kenya.

\subsection{Research Objective}

The objective of the research is to explore the significance of African Ubuntu moral theory in the control of public sector corruption in Kenya.

\section{Theoretical Framework}

This study is informed by Ubuntu moral theory. Ubuntu is a philosophy and way of life that has for many centuries sustained African communities. The word ubuntu is found in many African languages: "ubuntu" is from IsiNguni; "botho" is Sesotho; in XiTsonga the word is translated as "vumunhi"; while in TshiVenda it is "uhuthu." According to Kamwangamalu (1999) [8], this concept has phonological variants in a number of African languages: umundu in Kikuyu and umuntu in Kimeru, both languages spoken in Kenya; bumuntu in kiSukuma and kiHaya, both spoken in Tanzania; vumuntu in shiTsonga and shiTswa of Mozambique; bomoto in Bobangi, spoken in the Democratic Republic of Congo (DRC); gimuntu in kiKongo and giKwese, spoken in the DRC and Angola, respectively.

Ubuntu is not only about human acts, it is about being; it is a disposition, and it concerns values that contribute to the well-being of others and of the community. Mnyandu (1997) [9] best expresses this notion when he says that Ubuntu is not merely positive human qualities, but the very human essence itself, which enables human beings to become abantu or humanised beings, living in daily self-expressive works of love and efforts to create harmonious relationships in the community and the world beyond. In this framework, Ubuntu is a determining factor in the formation of perception of African society about what is good or bad behaviour (Broodryk, 1997) [10].

Ubuntu is inclusive, and is best realized and manifested in deeds of kindness, compassion, caring, sharing, solidarity and sacrifice. These acts produce positive results for both individuals and community. They make it possible for an individual to count on and expect the meaningful support of fellow human beings. People are enabled to share resources with which they are blessed. These values, furthermore, maintain and preserve community cohesion as they contribute positively to those in need (Grange, 2015) [11].

The idea that one ungumntu (is a person) shows that to have full humanity is to have managed to live out and demonstrated positive qualities which are beneficial to good neighbourliness and to have matured in positive human relations. Carrying out duties that contribute to the well-being of others transforms and 
confers on an individual the full status of a being human. A person's humanity is discovered and recognized through good relations and interactions with others and the nature of interaction is meant to foster the common good of the community.

\section{Literature Review}

Maboloc (2008) [12] rightly argues that human development is globally confronted by corruption. To avert the negative effects of corruption, Lewis (2007) [13] opined that the society needs people with shared moral values for the satisfaction of everyone. Additionally, the old Roman savants had a comparative origination of what benefits everyone. Marcus Tullius Cicero (106 BC - 43 BC), around 50 BCE, characterized a "group" or "republic" as not any assortment of individuals united, but rather a gathering of individuals related for equity and association for the benefit of all. Christian scholars have likewise investigated the thought of the common good. In The City of God, Augustine (354 - 430) took up Cicero's meaning of a republic as a group joined by their quest for the benefit of all and contended that to seek after the benefit of everyone is to deliver unto God the adoration and love that is His due. Thomas Aquinas (1225 - 1274) contended that God's own will is the benefit of everyone. For Aquinas (1972), an administration qualifies as oppressive when it is not coordinated to the benefit of all. Without parting from these early traditions, current Christians have additionally joined the language of the benefit of all in contemporary religious domain. The Second Vatican Council comprehended the common good as the whole of social conditions which permit individuals to carry on with significant lives.

The Principle of the Common Good is one of the significant features in the teachings of the Church. As indicated by the Social Teachings of the Church, it alludes to the assortment of social conditions that make it feasible for every community of people and individuals to accomplish their potentials.

According to the Church, the standard of the common good can be developed through three levels: the social level, individual level, and the political level. On the social level, the Church clarifies that a government that desires and plans to assist individuals is a government that has the benefit of everyone as its essential objective (Compendium of the Catholic Church, 347) [14]. However, this is the very idea that corruption nullifies. Corruption meddles with the people's capacity to look for and practice common good.

On the individual level, the Church clarifies that everybody has an obligation to advance the common good (Compendium of the Catholic Church, n. 352) [14]. The accomplishment of the common good requires the consistent capacity and work for the benefit others like it were one's own benefit. The obligation regarding accomplishing the common good has a place additionally with the State, since the benefit of everyone is the explanation that the political power exists (Compendium of the Catholic Church, n. 355) [14]. The State, indeed, should ensure evenhanded appropriation of public assets so that all citizens may benefit 
from the public resources.

Also, the Church's teaching on the Principle of the Common Good is anchored on the Church's teachings on Respect for Human Dignity. The Christian conviction of the dignity of individuals is generally traced back to the creation story, particularly the imago Dei (Gen. 1: 26-27) [15]. Human dignity suggests that every individual is deserving of honor and regard for what their identity is and not only for what they can do. Accordingly, human dignity cannot be procured and it cannot be removed (Neal, 2015) [16]. This implies that people should uninhibitedly partake in the advantages of their resources.

Where and when the privileges of citizens are disregarded by not profiting with the resources intended to change their lives, there is an infringement of their dignity. In the encyclical, Laudato Si, Pope Francis (2015) [17] noticed that more energy is displayed in securing different species than in safeguarding the dignity which all people share in equivalent measure. Where people and groups profit with resources meant for them, there is room and opportunity for them to develop. Notwithstanding, corruption denies human dignity since it is the wellspring of underlying hindrances that deny individuals the material and intellectual products that they ought to enjoy.

Within the African setup, The Principle of the Common Good and Respect for Human Dignity is basically encapsulated in the Ubuntu Moral Theory. Placide Tempels (1906-1977) held that the Bantu is a force that requires individuals to participate in connection with others. According to him, it is by adhering to the moral guidelines that the Bantu people are recognized in public. Following Tempels (1959) [18], Mbiti (1969) [19] contends that an individual owes their reality to others. The group/community should consequently, make the individual and the individual makes the group/community. Like Mbiti (1969) [19], Menkiti (1984) [20] held that for personhood to be accomplished, an individual needs to go through a long interaction of social rituals and the community has the responsibility in teaching certain moral standards to the person. These moral standards are vital in sustaining the person to turn into a fully functional individual who has the common good of the community at heart.

In Gyekye's (1997) [21] thought, the core of an African life lies in the benefit of everyone. For Masolo (2010) [22], the information on communitarian values is given to people both through inception rituals and arbitrarily over the span of regular day to day existence where individuals gain from the experiences of others in the community. The final result of this interactive learning, in Bujo's (2001) [23] opinion, is an African whose acting and believing is consistently in tandem with others and who is ready to make a moral decisions for the benefit of all.

Moreover, there are four African foundations of Ubuntu moral hypothesis. They include holism, vitalism, spiritualism and communalism. Holism relates to the requirement for agreeable relationships between individuals. For spiritualism, Africa's legacy is a climate where religion pervades all degrees of life (Mbiti, 1969) 
[19]. Africa acquires a strict climate where each individual is so submerged in religion that individuals conveys religion in the planting field, to the brew party, to the memorial service functions, to class and to the political rallies. Besides, African religion is not principally for the individual, rather it is for the community of which each individual is a part. To be human, in the African culture, is to participate in religious activities of the community. The central aim of African spiritualism is to structure peoples' practices with moral dictates such as love, goodness, kindness, heavenliness, and equity (Magesa, 1998) [24], which are all geared towards the benefit of all in the community.

Concerning vitalism, Placide Tempels (1906-1977) held that Bantu people is a living power, a preeminent power that was made and called by God to partake in his creation. For Tempels (1959) [18], Bantu people, as essential power, have to participate in the growth of the entire community. It is by participating in the development/growth of the entire community that an individual grows. This means that the interests, fortitude, fellowship and correspondence in the community is vital since one's life force relies upon the life forces of others and creatures (Magesa, 1998) [24]. For Tutu (1999) [25], Ubuntu is about the actual substance of being human, that is, neighborliness, concern, mindful and caring (Tutu, 1999) [25]. In this view, Ubuntu cannot be isolated from the very existence of an African. It is the prism through which Africans decipher reality.

Ubuntu is to be in fellowship with others. Africa has no disengaged people. The individual owes their reality to others including those of past ages, the peers and the group of persons yet to come. The community should subsequently, mould people as per the social qualities that protect the community's moral framework (Masolo, 2010) [22]. For Menkiti (1984) [20], the idea of personhood cannot be diminished to the Cartesian cogito ergo sum (I think therefore I am). In Africa, the truth of the community outweighs the truth of individual life narratives. Without the community, the individual cannot exist. For personhood to be fully achieved, an individual needs to go through a long cycle of social and custom change and the community plays a part in recommending certain moral standards to the person. Bujo (2001) [23] properly hypothesized that the way that individuality is indivisible from the communitarian idea of human life in an African culture suggests that each individual needs to contribute to the benefit of the community.

The support for the African Ubuntu moral theory to deal with corruption rests in the contention that it offers important knowledge through its spiritualism, vitalism, communalism, and holism which structure the African perspective on the benefit of everyone. In her proposition about corruption and its associated methodologies in Africa, the previous Minister of Public Administration, FraserMoleketi (2007) [26], likewise, applauded Ubuntu as the quintessence of a worthy framework that supports Africa's obligation to combat corruption since it is germane to the Africans.

Through content analysis of the accessible literature with respect to a moral answer for the tenacious corruption in Kenya, this paper has set up corruption 
as an ethical issue, and thus, it requires moral development of citizens (Kinoti, 1994 [27]; Bafinamene, 2016 [28]). Gyekye (1997) [21] rightly argues that ethical formation will give an enduring answer to persistent corruption in Africa. Africa needs people of integrity and capacity to contribute to the common good of everyone. Be that as it may, such people should be formed through a cautious moral formation (Kinoti, 1994) [27]. This paper also contends that the issue of persistent corruption in Kenya requires a considerable moral formation that includes a shift in the current individualistic worldview and adoption of a communitarian worldview. In this line of thought, the old worldview-an individualistic worldview — ought to be broken to clear way for another worldview—-the moral world view that caters for the benefit of everyone.

Gyekye properly notes that if a communitarian culture is to be acknowledged in Africa, there is "need for moral training" (1997: p. 204) [21]. This paper, subsequently, attests that training in Ubuntu morality is vital to the change in perspective imagined from an individualistic ethical perspective to the morals that benefit everyone in the society, which this paper imagines to be the way to diminishing run-away public corruption in Kenya.

The suitability of Ubuntu morality has also been upheld by Makuvaza (2008) [29] contending that the educational framework in Zimbabwe is alien to the Zimbabweans. It does not take into consideration the native worldviews of Zimbabweans. For Makuvaza (2008) [29], the Zimbabwean educational framework remains established in the Western way of thinking and accordingly keeps on being strange to the Zimbabweans delivering reality as mimetic and inauthentic. Makuvaza (2008) [29] accordingly contended that legitimacy, and, thus, importance must be achieved with the recovery of the native Zimbabwean way of thinking established in the way of thinking of hunhul ubuntul unhulvunh. It is when hunhu begins to inform the Zimbabwean educational framework that it becomes certified in light of the fact that it is a way of thinking that is apropos to Zimbabweans. Hunhu can possibly recover the African social qualities by bringing into fruition the creation of munhu ane hunhu (a total, taught individual) i.e., a person in the fullest and noblest sense, one who is "mindful, unassuming, insightful, obliging, savvy, liberal, affable, socially developed, temperate and favored" (Venter, 2004) [30].

In Tanzania, literature shows that one of the goals in school educational plan is to instill virtues in students yet at the same time, school leavers have been associated with immoral practices. Despite the nation being commended as quite possibly the steadiest and serene nations in Africa, Ingber (2013) [31] contends that the rising improper practices have transformed the country into around. Corruption is persistent in Tanzania, that regardless of the government's endeavors, corruption is reliably referred to as one of the significant limitations for development in Tanzania (Lindner, 2014) [32]. Since these indecent occurrences are being done by educated individuals, Ngussa, Makewa and Allida (2016) [2] appropriately contended, though with no unmistakable guide for a worth based educational procedure, that there is a need for an education framework in Tanzania to 
concoct systems that would preserve the moral integrity of Tanzania.

All things considered, Odundo and Ganira (2017) [33] appropriately believed that by securing values, children would become helpful individuals to the community and to themselves. For them, the educators have the obligation of forming the students by teaching suitable qualities for change and moral direction. The authors properly thought, but with no unmistakable guide for moral training, that reinforcing Value Based Education (VBE) in schools would be an empowering platform for the realization of Kenya's Vision 2030. Although this paper agrees with Odundo and Ganira (2017) [33] on the role of schools in value education, it thinks that virtue training is not just the sole prerogative of the schools, but a function of the entire community called Kenya. It is this obligation of the entire Kenyan people that this paper contends for the role of the Church in instigating moral ideals by incorporating Ubuntu moral hypothesis in pastoral ministry.

\section{Justification for Ubuntu Morality}

The preference for Ubuntu moral theory is legitimized by the contention that Ubuntu is to be human, which is, to be affable, cordial, mindful and merciful (Tutu, 1999 [25]; Munyaka \& Motlhabi, 2009 [34]) not exclusively to ones kinfolk and kith, but to everyone. A community that is mindful, tolerating and humane, as needed by Ubuntu, will consider it to be untrustworthy, for example, for people to discretionarily waste public assets for private gains.

Gyekye (1997) [21] holds that African states are composed of different groups and organizations which are of various structures and shapes. Individuals then participate in these groups or organizations as members. Additionally, Gyekye (1997) [21] recognizes ethno-cultural and multicultural communities. An ethnosocial/cultural community is a group of individuals who are connected by some inborn ties. For instance, individuals of the Ameru ethnic community in Kenya include individuals of Igembe, Tigania, Imenti, Igoji, Muthambi, Chuka, Mwimbi, Tharaka and Miutuni. They accept to be linked by a similar culture and history. They form an ethno-cultural community.

A multicultural community is formed when different ethno-social networks combine. As Gyekye (1997) [21] rightly opines, Ubuntu attributes like solidarity, fortitude, genuineness and union, which are showed in ethno-cultural communities, are missing in a multicultural community. It is inside this setting that corruption is conceptualized. For instance, a person who has been blamed for corruption will not see himself/herself as the denounced, however will see his/her community as the accused. That is, the individual showcases faithfulness to the ethno-cultural community than to the multi-cultural community.

This foregoing conversation shows that fairness can be more grounded in ethno-cultural communities than in multicultural networks. However, Kenya, as a state, is a multicultural community. Accordingly, the crucial inquiry that this proposition wrestles with at this point is that if unbiasedness can be successfully 
practiced in ethno-cultural communities, how might the standards of fairness and cooperation in the ethno-cultural communities be developed and polished in a multicultural community called Kenya? Communitarianism (an Ubuntu dictum) should overrun the state since it finds its beginnings in native ethno-cultural communities in Kenya where individualism is never acknowledged. Ubuntu Moral Theory necessitates that those concerned about battling corruption foster an ethical framework that capitalizes on developing temperance among citizens from whom local officials would arise. Kenya should explicitly propagate qualities like respectability, decency, genuineness, discretion, and obligation to public good.

However, how might the Ubuntu moral rule/hypothesis be developed in the general public? There are various ways that can be explored, such as the role of teachers, parents and political leaders. However, this paper analyses the role of the Church. As for Heidt (2010) [35], religion has an amazing impact on human conduct. The lessons of different practices incredibly impact how individuals act towards others. Chen and Liu (2009) [36] guaranteed that religion is viewed as the most significant and stable social power in molding a person's life. Teymoori, Heydari and Nasiri (2014) [37] revealed that religion is a social establishment that significantly impacts people's practices and every day activities.

The connection between religious adherence and morality has been a subject of interest for some scientists as the years progressed. Rossano (2008) [38] accepted that religion involves virtues and principles and that adherence to strict religious practice is viewed as a conscious moral practice. However, the case of a connection between religious adherence and profound moral thinking was vigorously questioned by other scholars. Kohlberg (1981) [39] contended that religious adherence and moral thinking are innately disconnected since ethical thinking and religion address two unrelated spaces of human concern. But, later examinations showed that Kohlberg's attestation of unrelatedness is an error. Consequently, Glover (1997) [40] set off to additionally test whether adherence and moral thinking are connected. He looked at individuals from strict gatherings across the traditionalist moderate-liberal range and tracked down that the connection between strict religious adherence and moral thinking was directed by what sort of teachings these people receive from the religions.

As indicated by Duriez and Soenens (2006) [41], in a strict religious community whose lessons incorporate principled moral thinking, individuals are probably going to show expanded inclination for this sort of principled moral thinking. Interestingly, religions whose lessons do exclude principled moral thinking, individuals are probably going to show diminished inclination for this sort of thinking. Also, scholars have showed that strict teachings (reasonableness, resilience, and unity) have been found to have a higher prescient capacity on the ethical judgment (Miltiadis \& Ioannis, 2017) [42] of people.

Within the African setting, religion saturates all parts of life. In African life, the individual is drenched in strict religious interest that begins before birth and proceeds into the afterlife. For the African, to live is to be involved in religious 
practice (Mbiti, 1969) [19]. Both the universe, and human life, are seen and experienced according to a strict religious viewpoint (Obaji \& Swart, 2015) [43] because of the fact that African societies are generally sacral (Kirwen, 2008) [44].

While the African strict religious legacy has an intense power that actually impacts the qualities, character and viewpoints of Africans, Christianity and Islam have likewise become significant wellsprings of impact in Africa. Christianity has been in Africa for hundreds of years and its huge impact is irrefutable. Proof of such an impact can be seen in, for instance, the quantity of Christian chapels, and Christian institutional foundations in numerous African nations. Islam has additionally been in Africa for an extensive stretch of time that has driven Mbiti (1969) [19] to remark that these two religions can be both said to have become native in Africa.

Besides, African political class has frequently depended on religion in their extraordinary contest for the assets of political force and notoriety. Religion is utilized in political missions as an instrument of impact. The contemporary African urban communities present a situation where more private structures are being changed over into prayer houses, and stadia are being utilized for religious campaigns. Inside this religious blast, the quantity of priests, ministers, evangelists, faith healers, prophets, sheikhs, and imams is expanding (Nwankwo, 2015) [45]. But, if religion is so much engrained in African culture, how can the remarkable instances of corruption be explained?

Despite the fact that religion is thriving in Africa, many sub-Saharan African nations are poor and among the world's corrupt countries (Obaji \& Swart, 2015) [43]. A large number of the people who rush to the temples and churches are at one time or the other in such exercises as tax avoidance, giving and getting phony receipts, bringing in counterfeit medications, and pay offs (Ehusani, 2003) [46]. Does it imply that religion is presently not a wellspring of moral motivation in Africa and in Kenya, specifically? Could it be that the lessons of the predominant religious movements in Kenya do exclude principled moral thinking? This paper theorizes that religious communities in Kenya, just as in other African nations, have not taken into cognizance Ubuntu moral worldview that is fitting to Africans. This suggests that for persistent corruption to be dealt with in Kenya, there is need for the religious movements to reexamine and take on Ubuntu moral theory that can adequately prompt individuals' inward change. This individual inward change will then lead to social change, as all individuals will have accomplished a worldview that works for the common good.

\section{Implementation Strategy}

This paper contends that realizing that corruption hurts all Kenyans, does not really prompt conquering corruption. In addition, knowing the anti-corruption approaches in Kenya does not really imply that an individual will not participate in corruption. For individual Kenyans to follow up on the anti-corruption strategies and different structures set up to curb corruption in Kenya, moral devel- 
opment is here advocated for. People with maturely developed moral conscience will decide to perform what is right for everybody in the society.

This paper infers that the Church ought to go past simple preaching by more deliberately associating its lessons with the public life of individuals consequently invigorating their conscience. This more deliberate way targets arousing the conscience of people by bringing the people into a vivacious discussion with the social teachings of the church versus the social reality where individuals live and work.

Incorporating social activism into the Small Christian Communities (SCCs), Women Associations, and Men Associations' gatherings and exercises: this granular perspective would help the Church to coordinate reverential existence with social activism. To disregard social activism for holy and reverential life is to overlook the Christian prophetic obligation. The peoples' week by week gatherings should be incorporated with a profound investigation of the social, political and financial issues influencing the local area, especially corruption. Holland and Henriot (1980) [47] properly see that social examination that involves See, Judge and Act measure is essentially an expansion of the rule of wisdom, moving from the individual domain to the social domain.

This social investigation would offer people capacities to acquire a more complete image of a social circumstance by investigating its primary and chronicled relations. Through friendly examination, individuals from SCCs will obtain the apparatuses to make a superior world or local area for the image of God. These apparatuses will empower them to recognize every one of the variables engaged with a social issue so that right reactions might be picked. When applied to the instance of corruption, this social investigation measurement will predict individuals from the gatherings turning out to be more mindful of the social signs of corruption in Kenya.

Enabled by strict stories, both scriptural and social, social activism visualized in this system will permit individuals from the Church to partake in coordinated peaceful demonstrations to fight the attacking corruption in Kenya. Strict accounts for this situation would infer certain accounts of Christian saints who have battled and set out their lives for political change across the globe. The Church administration should archive these accounts to retell narratives of brave activity and pivotal triumphs, empowering contemporary listeners to rehash the deeds of past legends. As well as forming bunch personality, such accounts can assist with inspiring intentional activities in quest for political change since they appeal to the conscience of the people.

It ought to be highlighted that the activation measurement of stories is their capacity to introduce an elective vision of things to come. Stories regularly persuade activism not basically in light of their vision of the past but instead on the grounds that individuals track down a projected future in such accounts. For instance, strict accounts helped shape famous perspectives about legislative issues in El Salvador, including thoughts regarding equity and unfairness and the pre- 
requisites of individual good conduct, just as dreams of a superior future. The accounts appeared as anecdotes about affliction and courageous penance. The stories drew on strict and common sources, joining records of early Christian saints, contemporary church figures like Oscar Romero, political legends like Farabundo Marti and Che Guevara, and, not least, saints inside families, neighbors, and nearby activists. What held these different sources together and gave mainstream saint stories their one of a kind logical and assembling power, was their apparent correspondence to Jesus' misery and demise. As such, Christians in El Salvador comprehended contemporary penances as proofs of confidence in Jesus, yet as imitations of Jesus' own behavior. The saint story was in this way imitated in resistance radio and print media and the way of talking of resistance pioneers; in well-known melodies, both strict and common; in banners and spray painting celebrating legends; and in consistent reflection and discussion in grassroots little Christian associations. Saint accounts passed on a promise to activity for the little Christian developments in El Salvador. The people met around their memory, and perceiving how important individuals have succumbed to the purpose of the country, Christian got an inspiration to continue fighting for justice (Peterson, 1996) [48].

The Pastoral Letters: Church's initiative ought to engage the entire congregation in the definition and execution of pastoral letters. Besides, pastoral letters ought to be written in a language which is open to all in the general public. Composing pastoral letters utilizing tangled sentence structure that is out of reach to the majority will naturally lock out pivotal specialists of social transformation. Pastoral letters and lobbies for harmony and equity should arrive at the uninformed individuals from the little Christian communities enduring the worst part of corruption. Moreover, if possible, clerics, ministers, religious adherents, and the common people ought to effectively partake in political issues, for example, challenging corruption in public fora. This is critical as it will extend the ethical creative mind of the Christian group, arousing their cognizance and at last become an indication of expectation for the individuals who live in oppression (Ela, 1986) [49].

Church Ministers: first, there ought to be a supported endeavor of the individual ministers to include corruption and anti-corruption for their messages, especially their preaching. Second, the ministers ought to continually denounce and reproach the state for widespread corruption in the country. Third, they should give direction to the congregation on how believers could shun corruption. Fourth, the ministers ought to coordinate and partake in different public anti-corruption gatherings, studios and meetings, and start organized short courses in advancing anti-corruption initiatives in their parishes. At last, the Church should team up and band together with both nearby and worldwide offices in anti-corruption activism.

\section{Conclusion}

In this paper, an endeavor has been made to foster a standardizing position that, 
whenever taken, would help in resolving the issue of corruption in the public service in Kenya. The paper has contended that anti-corruption legal frameworks ought to be complemented by a concentration on individual characters. To foster people of character, moral formation is essential. The paper has then argued that virtue formation is best achieved through conscience formation and conscience formation is best done by Christian churches particularly through Christian narratives. However, this virtue formation ought to take a moral theory into consideration that is germane to Africans. In this regard, this paper has argued that Ubuntu moral theory is best suited as a paradigm of conscience formation in Kenya as it resonates with the African world view and the majority of the African population, south of the Sahara would easily identity with Ubuntu moral concepts. As a result, the paper has identified some of the possible enforcement strategies that the Christian churches in Kenya can utilize in the formation of conscience. Among them: the use of pastoral letters, integrating social activism into the Small Christian Communities (SCCs), Women Associations, and Men Associations' meetings and activities, and the role of clergy in admonishing the faithful on virtue. In terms of limitations of this current paper, this paper is limited in scope and discussion to a literature review on the applicability of Ubuntu moral theory in character formation. The paper would recommend a field research on, as an area of future researches, the perception of Kenyans on the applicability of Ubuntu morality as an anti-corruption initiative. Second, on how the Ubuntu moral rule/hypothesis can be developed in Kenya, there are various ways that can be explored, such as the role of teachers, parents and political leaders. However, this paper has limited its scope to the role of the Church. This further leaves room for future research on other dimensions through which Ubuntu morality can be propagated in Kenya and as well as the rest of Africa. Finally, this paper is also limited in scope with regard to the implementation strategy in Ubuntu moral paradigm. The paper has limited its discussion on the role of the Christian Churches, yet there are several religious movements in Kenya such as Islam, Hinduism, Buddism. This, therefore, presents a gap for future study on how other religions, operative in Kenya, can implement an Ubuntu dictum among their adherents.

\section{Conflicts of Interest}

The authors declare no conflicts of interest.

\section{References}

[1] Dimant, E. (2013) The Nature of Corruption: An Interdisciplinary Perspective. Economics. http://www.economics-ejournal.org/economics/discussionpapers/2013-59

[2] Ngussa, M.B., Makewa, N.L. and Allida, D. (2016) Integration of Moral Values in the Secondary School Humanities Curriculum across Lake Zone, Tanzania. International Journal of Educational Policy Research and Review, 3, 117-125.

[3] Mwenzwa, E.M. (2013) Corruption in the Utilization of Constituencies Develop- 
ment Fund: Implications and Remedies. In: Ontita, E.G., Mwenzwa, E.M. and Misati, A.J., Eds., Themes in Contemporary Community Development in Africa: A Multi-Disciplinary Perspective, Delizon \& Elvee Academic Book Publishers, Lagos, 116.

[4] Kenya Anti-Corruption Commission (2010) Sectoral Perspectives on Corruption in Kenya: The Case of the Public Health Care Delivery. Research and Policy Department.

[5] Ethics and Anti-Corruption Commission (2016) National Ethics and Corruption Survey.

[6] National Cohesion and Integration Commission (NCIC) (2016) Ethnic and Diversity Audit of the County Public Service. NCIC Publication.

[7] Oindo, J.O., Oyugi, E. and Samita, Z. (2021) How African Kinship System Contributes to Corruption in Kenya. Open Journal of Social Sciences, 9, 21-38.

https://doi.org/10.4236/jss.2021.95003

[8] Kamwangamalu, M.N. (1999) Ubuntu in South Africa: A Sociolinguistic Perspective to a Pan-African Concept. Critical Arts, 13, 24-41. https://doi.org/10.1080/02560049985310111

[9] Mnyandu, M. (1997) Ubuntu as the Basis of Authentic Humanity: An African Christian Perspective. Journal of Constructive Theology, 3, 81 .

[10] Broodryk, J. (1997) Ubuntuism as a Worldview to Order Society. University of South Africa, Pretoria.

[11] Grange, L.L. (2015) Ubuntu/Botho as ecophilosophy and ecosophy. Journal of Humanity and Ecology, 49, 301-308. https://doi.org/10.1080/09709274.2015.11906849

[12] Maboloc, B. and Ryan, C. (2008) The Concept of Human Development: A Comparative Study of Amartya Sen and Martha Nussbaum. Master's Thesis, Linköpings Universitet, Linköping.

[13] Lewis, H. (2007) Excellence Without a Soul: How a Great University Forgot Education. East China Normal University Press, Shanghai.

[14] Catholic Church (2005) Compendium of the Catechism of the Catholic Church. Canadian Conference of Catholic Bishops, Ottawa.

[15] Hitchcock, F.R.M. (1922) St. Augustine's Treatise on the City of God. Society for Promoting Christian Knowledge, London.

[16] Neal, T. (2015) What Is "Human Dignity?"

[17] Pope Francis (2015) Laudato Si. Paulines Publications Africa, Nairobi City.

[18] Tempels, P. (1959) Bantu Philosophy. Presence Africaine, Paris.

[19] Mbiti, S.J. (1969) African Religions and Philosophy. Heinemann, London.

[20] Menkiti, I. (1984) Person and Community in African Traditional Thought. In: Wright, R.A., Ed., African Philosophy: An Introduction, University Press of America, Lanham, 171-181.

[21] Gyekye, K. (1997) Political Corruption: A Philosophical Analysis of a Moral Problem. Sankofa Publishing Co. Ltd., Accra. https://doi.org/10.1093/acprof:oso/9780195112252.003.0007

[22] Masolo, D.A. (2010) The Self and Community in a Changing World. Indiana University Press, Bloomington.

[23] Bujo, B. (2001) Foundations of an African Ethic: Beyond the Universal Claims of Western Morality. Paulines Publications Africa, Nairobi City.

[24] Magesa, L. (1998) African Religion: The Moral Traditions of Abundant Life. Paulines 
Publications Africa, Nairobi City.

[25] Tutu, D.M. (1999) No Future without Forgiveness. Doubleday, New York. https://doi.org/10.1111/j.1540-5842.1999.tb00012.x

[26] Fraser-Moleketi, G. (2007) Towards a Common Understanding of Corruption in Africa. International Journal of African Renaissance Studies, 2, 239-249. https://doi.org/10.1080/18186870701751723

[27] Kinoti, G. (1994) Hope for Africa: And What the Christian Can Do. AISRED.

[28] Bafinamene, C.K. (2016) Church and Moral Formation in an African Context: A Critical Appropriation of Stanley Hauerwas' Proposal. University of Pretoria, Pretoria.

[29] Makuvaza, N. (2008) Conquest, Colonial Education and Cultural Uprootedness in Africa: The Role of Education for Hunhu/Ubuntu in De-Rooting the African in Zimbabwe. Zimbabwe Journal of Education Research (ZJER), 20, 371-388. https://doi.org/10.4314/zjer.v20i3.44062

[30] Venter, E. (2004) The Notion of Ubuntu and Communalism in African Educational Discourse. Studies in Philosophy and Education, 23, 149-160. https://doi.org/10.1023/B:SPED.0000024428.29295.03

[31] Ingber, S. (2013) Pictures: Inside the Albinos in Tanzania.

[32] Lindner, S. (2014) Tanzania: Overview of Corruption and Anticorruption. U4 Expert Answers. https://www.transparency.org

[33] Odundo, P.A. and Ganira, K.L. (2017) Teacher Position in Spurring Value Based Education in Early Learning in Nairobi County, Kenya: Addressing Support of Values in School Environment. Journal of Education and Learning, 6, 194-203. https://doi.org/10.5539/jel.v6n3p194

[34] Munyaka, M. and Mokgethi, M. (2009) Ubuntu and Its Socio-Moral Significance. In: Munyaradzi, F.M., Ed., African Ethics: Anthology for Comparative and Applied Ethics, University of KwaZulu-Natal Press, Pietermaritzburg, 63-84.

[35] Heidt, M.R. (2010) Moral Traditions: An Introduction to World Religious Ethics. Anselm Academic, Winona, MN.

[36] Chen, S.-Y. and Liu, C.-C. (2009) Relationships between Personal Religious Orientation and Ethical Ideologies. Social Behavior and Personality, 37, 313-320. https://doi.org/10.2224/sbp.2009.37.3.313

[37] Teymoori, A., Arash, H. and Hedayat, N. (2014) Relationship between Dimensions of Religiosity, Authoritarianism, and Moral Authority. Social Compass, 61, 92-107. https://doi.org/10.1177/0037768613514320

[38] Rossano, J.M. (2008) The Moral Faculty: Does Religion Promote "Moral Expertise"? The International Journal for the Psychology of Religion, 18, 169-194. https://doi.org/10.1080/10508610802115727

[39] Kohlberg, L. (1981) The Philosophy of Moral Development: Moral Stages and the Idea of Justice. Harper \& Row, New York.

[40] Glover, R. (1997) Relationships in Moral Reasoning and Religion among Members of Conservative, Moderate, and Liberal Religious Groups. Journal of Social Psychology, 137, 247-254. https://doi.org/10.1080/00224549709595435

[41] Duriez, B. and Soenens, B. (2006) Religiosity, Moral Attitudes and Moral Competence: A Critical Investigation of the Religiosity-Morality Relation. International Journal of Behavioral Development, 31, 75-82. https://doi.org/10.1177/0165025406062127

[42] Miltiadis, P. and Ioannis, P. (2017) The Influence of Religiosity on Moral Judgment 
in Sport. Social Sciences.

[43] Obaji, M.A. and Swart, I. (2015) Religion and Social Transformation in Africa: A Critical and Appreciative Perspective. Scriptura, 114, 1-20. https://doi.org/10.7833/114-0-1115

[44] Kirwen, C.M. (2008) The Missionary and the Diviner. Orbis Books, Maryknoll.

[45] Nwankwo, S.C. (2015) Religious Boom and Moral Decadence in Nigeria: Implications for National Development. International Journal of Theology and Reformed Tradition, 7, 9-25.

[46] Ehusani, G. (2003) Religion and the Scourge of Corruption in Nigeria: Corruption, Accountability and Transparency for Sustainable Development. ALF Publications, Ota.

[47] Holland, J. and Henriot, P. (1980) Social Analysis: Linking Faith and Justice. Centre of Concern, Washington DC.

[48] Peterson, L.A. (1996) Religious Narratives and Political Protest. Journal of the American Academy of Religion, 64, 27-44. https://doi.org/10.1093/jaarel/LXIV.1.27

[49] Ela, J.-M. (1986) African Cry. Wipf \& Stock Publishers, Eugene. 